\title{
The Impacts of Content \& Language Integrated Learning (CLIL) Method on University Students' Reading Comprehension Skills in Indonesia
}

\author{
Muhammad Guntur*, Hamsu Abdul Gani, Mustafa \\ Universitas Negeri Makassar, South Sulawesi, Indonesia \\ Received June 12, 2021; Revised July 15, 2021; Accepted August 22, 2021
}

\section{Cite This Paper in the following Citation Styles}

(a): [1] Muhammad Guntur, Hamsu Abdul Gani, Mustafa, "The Impacts of Content \& Language Integrated Learning (CLIL) Method on University Students' Reading Comprehension Skills in Indonesia," Universal Journal of Educational Research, Vol. 9, No. 9, pp. 1656-1663, 2021. DOI: 10.13189/ujer.2021.090906.

(b): Muhammad Guntur, Hamsu Abdul Gani, Mustafa (2021). The Impacts of Content \& Language Integrated Learning (CLIL) Method on University Students' Reading Comprehension Skills in Indonesia. Universal Journal of Educational Research, 9(9), 1656 - 1663. DOI: 10.13189/ujer.2021.090906.

Copyright $\bigcirc 2021$ by authors, all rights reserved. Authors agree that this article remains permanently open access under the terms of the Creative Commons Attribution License 4.0 International License

\begin{abstract}
One of the problems of education in Indonesia is the low level of public literacy both on a national and international scale. One of the essential aspects of improving literacy is by generating interest in reading in college students. This study aims to test the effectiveness of the Content \& Language Integrated Learning (CLIL) method on students' reading comprehension skills. There were 40 participants involved in the study which were divided into two groups, namely the control class and the experimental class. All participants are students from the State Islamic Institute (IAIN) Palopo, South Sulawesi, Indonesia who are taking Indonesian language courses as a compulsory subject in higher education. To collect data, the researcher used an instrument in the form of a multiple-choice test which was given to both groups in the pretest and posttest sessions. The learning outcomes of the two test sessions were analyzed quantitatively using the SPSS 20.00 application. The results showed that the use of the CLIL method in Indonesian courses could improve students' reading comprehension skills. This is indicated by the difference in the average value between the pretest and posttest reading comprehension.
\end{abstract}

Keywords CLIL, Reading, Reading Comprehension

\section{Introduction}

In 2016, The World's Most Literate Nations (WMLN) released a literacy ranking of countries worldwide. This study was initiated by Miller J.W. As President of Central Connecticut State University conducted on more than 60 countries and stated that Finland is a country with the best literacy level. Other countries included in the world's best literacy category are Iceland, Denmark, Sweden, and Norway. Indonesia got a different result, which ranked 60th and was below other Southeast Asian countries, such as Singapore at 36th, Malaysia at 53rd, and Thailand at 59th [1].

Another study used as a reference in seeing the extent of a country's literacy level is the Program for International Student Assessment (PISA). This periodic survey is organized by the Organization for Economic Co-operation and Development (OECD) to measure the performance of high school students in three aspects, namely mathematics, science, and literacy. The survey results published in 2019 also still position Indonesia in the lowest ranking [2]. Despite the many controversies about this PISA study [3], the results of this study at least illustrate that literacy in Indonesia is still very minimal.

One reason for the low level of literacy is the lack of students' ability to master one of the language skills, namely reading comprehension skills. Reading comprehension as part of the discussion of Indonesian 
Language Courses plays an important role in improving student literacy. Reading comprehension is still considered a complicated and complex subject, both by students and based on the teachers' perspective [4]. The majority of students have difficulty finding information that is stated explicitly, recognizing the main idea, and making conclusions [5].

Given the importance of reading comprehension skills, lecturers must be able to present learning using the best learning method or approach. Of the many learning methods, Content \& Language Integrated Learning (CLIL) is a method that has the main focus not only on the linguistic aspect but also on the content aspect [6], [7]. With the CLIL method, students are directed to learn about communication and learn content through language [8].

CLIL is one of the most popular approaches to teaching in various disciplines through the target language [9]. In its development, teachers increasingly demand this method because it is related to the development of other skills. CLIL is defined as the method used to develop basic Interpersonal Communication Skills (BICS) and Cognitive Academic Language Proficiency (CALP) [7]. These two skills have developed through the 4C framework, namely Content, Communication, Cognitive, and Culture and are the main goals in education today.

The CLIL method has various advantages, one of which is to increase opportunities for language learning through the use of the target language in learning multiple subjects in the college curriculum [10]. This method can also generate intercultural or intercultural awareness in students to become global players in their future in the international market [11]. The method provides non-linguistic benefits by showing confidence and asking them nicely [12].

Several studies have been conducted by researchers with the theme of the CLIL method in learning reading comprehension. The use of the CLIL method turned out to be able to develop students' reading comprehension, vocabulary, and memory skills in learning English [13]. Another study stated that the CLIL method affected students with high and low intelligence in learning to read comprehension of junior high school students, specifically for English subjects [14]. In addition, students who were trained strategically using a particular method of reading (the CLIL method) appeared to increase greater metacognitive awareness [15].

There have been many studies using the CLIL method in learning reading comprehension. However, almost all of these studies are focused on learning English. There are still few researchers who pay attention to learning reading comprehension in Indonesian language courses. As a national language, the role of Indonesian as a scientific language in Indonesia needs to get significant attention, especially in the field of learning in universities.

Although the CLIL method is intended for learning a second language or foreign language (FL), this method can also be applied to learning the first language (Indonesian). This is based on the statement of Coyle, a leading CLIL theorist who stated that CLIL is concerned with the development of students' foreign language competence and the development of communicative competence in general in both foreign and first languages [16] [17]. Similar findings state that the CLIL method does not harm student competence in first language learning (L1) [18] [19]. The formulation of the problem in this research is; does the Content \& Language Integrated Learning (CLIL) method affect students' reading comprehension skills in Indonesian language courses?

\section{Literature Review}

\subsection{Content \& Language Integrated Learning (CLIL)}

CLIL is one of the general approaches proposed to accommodate the current concerns in acquiring two skills at once, namely language skills and knowledge content. In general, CLIL is an umbrella term for bilingualism, a content-based education that has been well established in education systems around the world over the last two decades [20]. This method is also present as a response to the result of widespread recognition that providing curriculum content in a second (target) language can be beneficial in increasing subject knowledge and target language skills.

This approach has been popularly adopted into the higher education area, even in European countries [21]. The term CLIL first appeared in the early 1990s as a pragmatic solution to the needs of European countries. These needs are related to pluralism for market mobility, academic and social needs [22]. The CLIL concept is likened to scaffolding or proximal growth zones and signals mediation by emphasizing the need to build knowledge of non-language content.

The CLIL method can also be equated in meaning with several other learning method terms. According to Burrows [23] methods similar to CLIL include (a) learning in improving content or content-enhanced teaching, (b) integration of language and content or integration of content and language, (c) content-based language learning or content-enhanced teaching based language instruction, (d) theme-based language teaching, (e) content-infused language teaching, (f) learning through an additional language, and others.

Furthermore, the CLIL approach is also interpreted as the primary communicative methodology that involves active student participation in developing their ability to acquire knowledge and skills through cognitive processes [24]. The CLIL approach is also characterized as a student-centred approach instead of a teacher-centred approach [25]. In other words, learning with the CLIL 
approach requires student participation and their interaction in using the target language in developing their communicative skills.

In other side, CLIL as a process that provides tools and opportunities for students to acquire the skills, knowledge, and competencies needed to carry out various tasks and goals in improving learning achievement. Furthermore, Awan \& Sipra [26] also explain the CLIL approach as an evolutionary process of learning theories combined with modern communication ideas supported by contextual factors. The contextual factors in question include issues of migration, globalization, and language politics.

CLIL is not a language teaching method alone or a content teaching method but combines the two [27]. This is based on the fact that the aspects of language and content have an equally important role. CLIL has a dual function in its method, namely to focus on the meaning or content and the form or language needed for the study of the content [28]. In this CLIL method, the language is positioned as a resource aspect rather than a system of rules. In other words, fluency is rated higher than the accuracy of the grammatical system. In this condition, the paradigm shift from implicit to more explicit language teaching has begun, but some still debate it [29].

The primary purpose of the CLIL method is to shape student activities to learn to use language and use language to learn [8]. Students' receptive skills will be practical if using this CLIL method. These receptive skills include vocabulary, morphology, creativity, emotion, and effectiveness. The CLIL method offers the authenticity of purpose that the communicative approach does not have [7]. With CLIL, it is hoped to manage the lack of relevance of language teaching such as grammar and students' motivation, including motivating their ability to use language, study content, learn the culture, and encourage student creativity [30].

In addition, the CLIL method is a language learning method that can combine several aspects. Some aspects referred to are content, communication, cognition, and culture [7]. Language is not only something that can be learned but also as a means of transforming knowledge. With this fact, it is very appropriate if learning to read comprehension in language uses the CLIL approach.

\subsection{Reading Skill}

Many people think of reading as a skill taught once. And for all in the first years of primary school. They view reading as a simple process, namely the reader trying to read the symbol/decode, finding a way to pronounce each word in a text, and automatically understanding the words' theme as they do every day [31]. On the other hand, reading is not an easy process to pick up the words on each text sheet. Reading is a complex problem-solving process in which the reader tries to integrate the words he reads with the ideas, memories, and knowledge generated by those words.

Reading is one of the most important language skills that must be developed since childhood. Parris [32] believes that the ability to read is a fundamental need to be able to participate in today's society and economy. Even people consider reading as the foundation of modern daily life [33]. This can be seen from the activities of people from waking up to going back to sleep which cannot be separated from reading activities. The various activities referred to include: checking messages and social media every morning, reading online news or magazines and newspapers, reading and signing different office and work files, and others. Of course, reading involves more than just the ability to recognize letters and translate words. Reading, in the end, is about how to build meaning from a text [34].

In the context of meaning in general, reading is a process that occurs when someone sees a text and how he interprets the text. Text and reader are two physical entities that are very important in reading [35], [36]. The writing process is the interaction between the reader and the text that produces meaning for the text. In line with this statement, Howell \& Nolet [37] explained that reading is an interactive process that uses code, context analysis, prior knowledge, language, and executive control strategies to understand the text.

Reading is a complex and diverse activity [38] and is a complicated skill because it requires a combination of attention, memory, perceptual processes, and comprehension processes [39] with various levels of cognitive processes necessary for reading. Reading cannot be considered a set of mechanical skills that must be learned once and for all but rather seen as a complex process to make meaning from the texts read for various purposes and various contexts.

Goodman [40] states that reading is a psycholinguistic process that begins with a linguistic surface representation encoded by an author and ends with a meaning constructed by the reader. That is, there is an essential interaction between language and thought in the reading process. Thus, reading not only includes encoding language or written words but also extends beyond information related to the world [41].

\subsection{Reading Comprehension}

Edge [42] explains that reading comprehension is a strategy that encourages students to use knowledge, experience, careful thinking, and evaluation to help them decide how to apply what they know to all reading situations practically. Reading comprehension is a cognitive or behavioural action used in certain textual conditions to improve several aspects of understanding. In addition, Medina [43] explains that reading comprehension is a complex process involving the interaction of the reader and the text using various skills. 
Reading comprehension is an activity of perceiving the vocabulary used in written texts and connecting them to achieve a comprehensive understanding [44]. Furthermore, reading comprehension is a complex skill because it requires other vocabulary and decoding skills. Pokharel [45] describes that reading comprehension involves the interaction of linguistic processing and conceptual processing, which results in constructing meaning or conceptual representation of a text in memory.

Reading comprehension is an activity to understand the text more deeply [46] Tampubolon [47] states that reading comprehension involves motor skills in the form of eye movements and involves thinking and reasoning to find and understand the meaning of written information. By the author/author. Dalman [48] also explained that reading comprehension is a cognitive reading activity to understand the contents/messages that have been read. In this context, readers are not only required to be able to pronounce letters and associate sounds into words, phrases, and sentences but are also required to understand the content of the text [49].

\section{Method}

\subsection{Research Design \& Participants}

This study aims to analyze the differences in students' reading comprehension learning outcomes using the CLIL method. Thus, this study uses a quasi-experimental research method with a pretest-posttest control group design. This design is a research design that is often used by researchers, especially in the field of education [46]. With this design, the researcher determines the participants based on the collected groups such as classes and does not determine the participants based on the random method [47].

There are two groups in this quasi-experimental research, namely the experimental group and the control group. Both groups received treatment in the form of pretest and posttest. The pretest is a test used to obtain initial data about student learning outcomes, while the posttest is a test at the end of learning after receiving treatment. The types of pretest $\&$ posttest questions that were applied to the two groups were the same multiple-choice test.

The participants in this study were students of the State Islamic Institute (IAIN) Palopo, South Sulawesi, Indonesia, taking Indonesian Language Courses. The participants of this study were divided into two groups, namely 20 students in the experimental group and 20 students in the control group. The experimental group was treated using the CLIL method, while the control group was treated using the conventional method.

\subsection{Data Collection}

Data collection in this study used an instrument in the form of a multiple-choice test with four answer choices. This test consists of five parts, and each part consists of 5 questions. Thus, the number of questions in the reading comprehension test in this Indonesian Language Course is 25 questions. The researcher developed the test based on the curriculum and Semester Lesson Plans (SLP) in the Indonesian language course with a discussion of reading comprehension. Before being used, the test instrument was tested for reliability with a result of 0.82 . These results are declared to have met the reliability criteria using Cronbach's alpha coefficient.

\subsection{Data Analysis}

After the data from the pretest and posttest were collected, then the data were analyzed quantitatively. Data analysis was carried out using SPSS 20.00 software by calculating the average score and standard deviation. In addition, the t-test was also calculated to compare the pretest and posttest scores on students' reading comprehension of the two groups, both the experimental and control classes.

\section{Results}

Data from the pretest and posttest sessions were analyzed by calculating the mean and standard deviation. The results of the analysis are presented in table 1 below.

Table 1. Pretest \& Posttest Results in Both Groups

\begin{tabular}{|c|c|c|c|c|c|}
\hline & & Pre-experiment & Post-experiment & Pre-control & Post-control \\
\hline \multirow[t]{4}{*}{$\mathrm{N}$} & Valid & 20 & 20 & 20 & 20 \\
\hline & Missing & 0 & 0 & 0 & 0 \\
\hline & $\begin{array}{c}\text { Mean } \\
\text { Std. Error Mean } \\
\text { Median } \\
\text { Mode } \\
\text { Std. Deviation } \\
\text { Minimum } \\
\text { Maximum }\end{array}$ & $\begin{array}{c}51.75 \\
1.929 \\
50.00 \\
45 \\
8.626 \\
40 \\
65 \\
\end{array}$ & $\begin{array}{c}80.00 \\
2.176 \\
80.00 \\
75 \\
9.733 \\
65 \\
100 \\
\end{array}$ & $\begin{array}{c}50.0000 \\
1.70139 \\
50.0000 \\
50.00 \\
7.60886 \\
40.00 \\
65.00 \\
\end{array}$ & $\begin{array}{c}65.2500 \\
1.17401 \\
65.0000 \\
65.00 \\
5.25031 \\
55.00 \\
75.00 \\
\end{array}$ \\
\hline & Sum & 2.500 & 40 & 1000.00 & 1305.00 \\
\hline
\end{tabular}


Table 1 informs the results of each test's descriptive statistical tests (pretest and posttest) for both groups, namely the control and experimental groups. The control group had an average pretest score of 50 with a standard deviation of 7.6, while the posttest average value of 65.25 with $\mathrm{sd}=5.25$. For the experimental group, the mean pretest score was 51.75 with a standard deviation of 8.626 , while the posttest means was 80 with a standard deviation of 9.733. Especially for the experimental group, the CLIL method treatment has increased the average score of students' reading comprehension from 51.75 on the pretest to 80.00 on the posttest. This increase occurred because of the treatment involving lecturers and students in the CLIL method used in the experimental group.

Table 2. Paired Samples Correlations

\begin{tabular}{|l|c|c|c|c|}
\hline & & $\mathbf{N}$ & Correlation & Sig. \\
\hline Pair-1 & $\begin{array}{c}\text { Pretest-Posttest } \\
\text { Experiment }\end{array}$ & 40 & .844 & .000 \\
\hline Pair-2 & $\begin{array}{c}\text { Pretest-Posttest } \\
\text { Control }\end{array}$ & 40 & .767 & .000 \\
\hline
\end{tabular}

Table 2, a paired sample correlations test was conducted to prove whether the difference between the pretest and posttest in the experimental group was genuine. From this test, it can be concluded that the two variables (in the practical class) produce a probability value (Sig.) of 0.844 . From these results, it can be interpreted that the correlation between the pretest and posttest is significantly related. This is based on the provision that if the probability value $<0.005$, then the relationship between the two variables occurs significantly.

Table 3 shows the paired sample test analysis results to test the effect of the CLIL method on students' reading comprehension skills. This study compares the experimental group and the conventional method in the control group. From the table, information is obtained that the probability value (p) is labelled with the symbol Sig. (2-tailed) for the experimental group (pair-1) and the control group (pair-2) is 0.000 . If this probability value is less than 0.005 , it can be concluded that there is a significant difference between the two scores in the two groups. Thus, the two groups are declared to have a significant difference because the probability value is 0.000 less than 0.005 . Even though the control group using the conventional method was stated to have significant differences, the average score was lower when compared to the experimental group.

\section{Discussion}

This study explores the effect of the Content and Language Integrated Learning (CLIL) method on students' reading comprehension skills. Based on the research findings, it can be concluded that the CLIL method has a significant impact on students' reading comprehension skills. Several studies on this topic also showed the same results even though they were conducted for English subjects. Sanad and Ahmed [13] claim that CLIL can develop students' reading comprehension skills in English, vocabulary, and memory. A slightly different finding was put forward by Segura et al. [48] who found that over the last few decades, there has been an increase in students' skills in aspects of grammar and reading skills only. This study claims that students' overall linguistic acquisition aspect is stagnant and tends to decline.

Several researchers have also carried out similar studies related to using the CLIL method for first language learning (L1). According to Vazquez \& Ordonez [49], CLIL in first language learning (L1) encourages and motivates students to participate in class. The CLIL method also developed L1 competence for 285 secondary school students in Spain using a reading comprehension test and a written production test [50]. Reading comprehension skills were assessed using a standard multiple-choice test (reading the text followed by comprehension questions). At the same time, written production was evaluated by writing an essay by selecting a particular theme.

The role of the CLIL method in language learning, especially in the aspect of reading comprehension, really supports the achievement of student learning outcomes. As mentioned in the literature review section, the CLIL method has two parts of emphasis, namely content and language aspects. Brown \& Bradford [51] asserted that the content and language aspects have the same position and portion. That is, students are required to understand the content, and at the same time, they also need to improve their language skills.

Table 3. Paired Sample Test

\begin{tabular}{|c|c|c|c|c|c|c|c|c|c|}
\hline & \multicolumn{5}{|c|}{ Paired Differences } & \multirow{3}{*}{$\mathrm{t}$} & \multirow{3}{*}{ df } & \multirow{3}{*}{$\begin{array}{c}\text { Sig. } \\
\text { (2-tailed) }\end{array}$} \\
\hline & & \multirow[b]{2}{*}{ Mean } & \multirow[b]{2}{*}{$\begin{array}{c}\text { Std. } \\
\text { deviation }\end{array}$} & \multirow[b]{2}{*}{$\begin{array}{l}\text { Std. Error } \\
\text { Mean }\end{array}$} & \multicolumn{2}{|c|}{$\begin{array}{l}95 \% \text { confidence interval } \\
\text { of the difference }\end{array}$} & & & \\
\hline & & & & & Lower & Upper & & & \\
\hline Pair-1 & Pretest-Posttest Ex & $6.53750 \mathrm{E} 1$ & 16.51679 & 2.61153 & 60.09267 & 70.65733 & 25.033 & 39 & .000 \\
\hline Pair-2 & $\begin{array}{l}\text { Pretest-Posttest } \\
\text { Con }\end{array}$ & $5.51250 \mathrm{E} 1$ & 9.67998 & 1.53054 & 52.02919 & 58.22081 & 36.017 & 39 & .000 \\
\hline
\end{tabular}


The importance of using the CLIL method in learning reading comprehension is undeniable [52] states that the CLIL method is influenced by the impact of globalization and technological advances on education. Much of the attention of teachers and researchers has been paid only to the effectiveness of various methods, focusing on language acquisition rather than students' content knowledge [53]. In addition, this method is also a learning method that is cost-effective, time-saving, stress-free, and student-centered [54]. Another study confirmed that with CLIL, students were actively involved in learning and reducing the use of textbooks [55], [56].

Apart from the above advantages, the CLIL method is also stated to have benefits in other aspects. Several learning approaches, including the CLIL method, have influenced the way students learn by doing [57]. In connection with changes in learning styles in the era of the industrial revolution 4.0, language learning is not only focused on teaching language intrinsically but also has attempted to provide an overview of interactions in various contexts [58]. In this case, the CLIL method offers a new perspective to improve understanding of the world through culture, language acquisition, and specific contexts [59].

For future research, especially in learning to read and understand Indonesian, researchers/teachers have to relate the CLIL method, which focuses not only on learning outcomes but also on other aspects. Aspects of motivation, increasing values \& character, and activeness can be investigated further so that the implementation of the CLIL method is not only focused on aspects of language and content. In addition, researchers and teachers can also explore various learning techniques used in the CLIL method to attract students' interest. A study on this topic was initiated by Puspitasari [60] who stated that quizzes, group presentations, group teaching, and group discussions were learning techniques mastered by students. In the future, the following research may also be able to expand its reach into this area.

\section{Conclusions}

This study explores the effect of the Content \& Language Integrated Learning (CLIL) method on the reading comprehension skills of university students in Indonesian language courses. The results of statistical tests indicate that this method affects students learning outcomes. This is indicated by the results of the t-test, which states that there is a significant difference between the pretest and posttest scores. From these results, it can be concluded that the lack of students' reading comprehension skills can be overcome by using the CLIL method. This method is relatively new and is based on technological advances in today's world. CLIL is considered one of the best methods that emphasize the linguistic aspect and give an equal portion to the content aspect. For that reason, language learning has to be approached with this method. It was also agreed by experts who stated that the CLIL method was designed to learn by doing and was flexible to be used in the context of diverse student backgrounds.

\section{REFERENCES}

[1] W. J. Miller and M. C. McKenna, World Literacy: How Countries Rank and Why it Matters. New York: Routledge, 2016.

[2] S. Safari, "Students' Perception of Teacher Guide on Reading Learning Based on Results of PISA 2018," Indonesian Journal of Educational Assessment, vol. 3, no. 1, pp. 32-41, 2020, doi: 10.26499/ijea.v3i1.56.

[3] S. Sjoberg and E. Jenkins, "PISA: A Political Project and A Research Agenda," Studies in science Education, pp. 1-20, 2020, doi: 10.1080/03057267.2020.1824473.

[4] J. J. Moore, S. S. McClelland, E. C. Alef, and E. D. Vogel, "The Simplicity and Complexity of Reading Comprehension," International Journal of Business and Social Science, vol. 7, no. 6, pp. 20-26, 2016.

[5] A. M. Elleman and E. L. Oslund, "Reading Comprehension Research: Implications for Practice and Policy," Policy Insights from the Behavioral and Brain Sciences, vol. 6, no. 1, pp. 3-11, 2019, doi: 10.1177/2372732218816339.

[6] D. Bayram, R. O. Ozturk, and D. Atay, "Reading Comprehension and Vocabulary Size of CLIL and Non-CLIL Students: A Comparative Study," Language Teaching and Educational Research, vol. 2, no. 2, pp. 101$113,2019$.

[7] D. Coyle, P. Hood, and D. Marsh, CLIL: Content and Language Integrated Learning. Cambridge: Cambridge University Press, 2010.

[8] E. N. M. De Diezmas, "The Impact of CLIL on the Acquisition of L2 Competences and Skills in Primary Education," International Journal of English Studies, vol. 16, no. 2, pp. 81-101, 2016.

[9] L. Salekhova and T. Yakaeva, "Implementation of A CLIL-module "Economics" for English Language Learners in Russia: Results and Challenges," The Journal of Asia TEFL, vol. 14, no. 4, pp. 816-823, 2017.

[10] J. Goris, E. Denessen, and L. Verhoeven, "The Contribution of CLIL to Learners' International Orientation and EFL Confidence," The Language Learning Journal, vol. 47, no. 2, pp. 246-256, 2019. doi $10.1080 / 09571736.2016 .1275034$.

[11] W. Pengnate, "Ways to Develop English Proficiency of Business Students: Implementation of Content and Language Integrated Learning (CLIL) Approach," International Journal of Education and Research, vol. 1, no. 8, pp. 1-12, 2013.

[12] W. Yang, "The Deployment of English Learning Strategies 
in The CLIL Approach: A Comparison Study of Taiwan and Hong Kong Tertiary Level Contexts," ESP Today: Journal of English for Specific Purpose at Tertiary Level, vol. 6, no. 1, pp. 44-64, 2018, doi: 10.18485/esptoday.2018.6.1.3.

[13] H. Sanad and M. Ahmed, "Using Content and Language Integrated Learning (CLIL) to Develop EFL Reading Comprehension Skills, Vocabulary Skills and Retention among College Students," Journal of Research in Curriculum Instruction and Educational Technology, vol. 3, no. 4, pp. 101-131, 2017, doi: 10.21608/jrciet.2017.24355.

[14] N. Hamidavi, M. Shekaramiz, and B. Gorjian, "The Effect of CLIL Method on Teaching Reading Comprehension to Junior High School Students," Bulletin de la Societe Royale des Sciences de Liege, vol. 85, pp. 1642-1652, 2016.

[15] Y. R. de Zarobe and V. Zenotz, "Reading Strategies and CLIL: The Effect of Training in Formal Instruction," The Language Learning Journal, pp. 319-333, 2015, doi: 10.1080/09571736.2015.1053284.

[16] M. Navarro-Pablo \& Y. L. Gandara, "The Effect of CLIL on L1 Competence Development in Monolingual Contexts," The Language Learning Journal, 2019, doi: 10.1080/09571736.2019.1656764

[17] M. Martinez-Andrian, M. J. Gutierrez-Mangado and F. Gallardo-del-Puerto, "Introduction: L1 Use in Content-based and CLIL Settings," International Journal of Bilingual Education and Bilingualism, vol. 22, no. 1, pp. 1-4, 2019. Doi: 10.1080/13670050.2018.1508279

[18] D. Madrid \& E. Barrios, "A Comparison of Students' Educational Achievement across Programmes and School Types with and without CLIL Provision," Porta linguarum, vol. 29 , pp. $29-50,2018$.

[19] M. Perez-Canado, "The Effects of CLIL on L1 and Content Learning: Updated Empirical Evidence from Monolingual Contexts," Learning and Instruction, vol. 57, pp. 18-33, 2018. Doi: 10.1016/j.learninstruc.2017.12.002

[20] D. Chostelidou and E. Griva, "Measuring the Effect of Implementing CLIL in Higher Education: An Experimental Research Project," Procedia - Social and Behavioral Sciences, vol. 116, no. 1982, pp. 2169-2174, 2014, doi: 10.1016/j.sbspro.2014.01.538.

[21] E. Arno-Macia and G. Mancho-Bares, "The Role of Content and Language in Content and language Integrated Learning (CLIL) at University: Challenges and Implications for ESP," English for Specific Purpose, vol. 37 pp. 63-73, 2015.

[22] D. L. Banegas, "Teachers Develop CLIL Materials in Argentina: A workshop Experience," Latin American Journal of Content \& Language Integrated Learning, vol. 9, no. 1, pp. 17-36, 2016, doi: 10.5294/laclil.2016.9.1.2.

[23] T. Burrows, "English \& Integrated water Resources Management: A Training Program for Mekong River Commission," ASIAN EFL Journal Research, vol. 15, no. 4, pp. 37-64, 2013.

[24] K. Suwannoppharat and S. Chinokul, "Applying CLIL to English Language Teaching in Thailand: Issues and Challenges," Latin American Journal of Content and Language Integrated Learning, vol. 8, no. 2, pp. 237-254,
2015, doi: 10.5294/lacli1.2015.8.2.8.

[25] K. I. Diéguez and M. Martínez-Adrián, "The Influence of CLCLIL on Receptive Vocabulary: A Preliminary Study," Journal of English Studies, vol. 15, pp. 107-134, 2017, doi: 10.18172/jes.3210.

[26] M. A. Awan and M. A. Sipra, "CLIL: Content based Instructional Approach to Second language Pedagogy," Arab World English Journal, vol. 9, no. 1, pp. 1689-1699, 2018, doi: 10.1017/CBO9781107415324.004.

[27] T. Harvey, T. Tihinen, K. Määttä, and S. Uusiautti, "Content and Language Integrated Learning in Practice: Comparison of three Cases," International Journal of Academic Research in Progressive Education and Development, vol. 2, no. 2, pp. 2226-6348, 2013.

[28] M. L. Prez-canado, "CLIL Research in Europe: Past, Present, and Future," International Journal of Bilingual Education and Bilingualism, vol. 15, no. 3, pp. 315-341, 2012.

[29] T. M. Wewer, "An Observation Tool for Comprehensive Pedagogy in Content and Language Integrated Learning (CLIL): Examples from Primary Education," Colombian Applied Linguistics Journal, vol. 19, no. 2, pp. 277-292, 2017, doi: 10.14483/22487085.11576.

[30] E. Harrop, "Content and Language Integrated Learning (CLIL): limitations and Possibilities," Encuentro, vol. 21, pp. 57-70, 2012.

[31] N. Gómez Torres and J. Ávila Constain, "Improving Reading Comprehension Skills through Reading Strategies Used by a Group of Foreign Language Learners," How, vol. 16 , no. 1 , pp. 55-70, 2009.

[32] S. R. Parris, L. B. Gambrell, and A. Schleicher, "Beyond Borders: A Global Perspective on Reading Comprehension," in Comprehension Instruction: Research-based Best Practices, L. C. Block and S. R. Parris, Eds. New York: The Guilford Press, 2008.

[33] N. M. Klapwijk, "EMC2 = Comprehension: A Reading Strategy Instruction Framework for All Teachers," South African Journal of Education, vol. 35, no. 1, pp. 1-10, 2015, doi: $10.15700 / 201503062348$.

[34] J. P. Williams, "Explicit Instruction can Help Primary Students Learn to Comprehend Expository Text," in Comprehension Instruction: Research-based Best Practices, L. C. Block and S. R. Parris, Eds. New York: The Guilford Press, 2008.

[35] U. Dewi and M. Salmiah, "Students' Reading Strategies at English Educational Department," Al-Ishlah: Journal Pendidikan, vol. 11, no. 1, pp. 126-140, 2019.

[36] S. Subadiyono, Pembelajaran Membaca. Palembang: NoerFikri, 2014.

[37] K. W. Howell and V. Nolet, Studyguide for Curriculum Based Evaluation: Teaching and Decision making. Belmont: Wadsworth Publishing, 2000.

[38] H. Demiroz, "Reading Strategies Employed by ESL/EFL Students," Cumhuriyet Universitesi Bilimler Dergisi, vol. 34, no. 2, pp. 81-86, 2010.

[39] W. Grabe, "Current Developments in Second Language 
Reading Research," TESOL Quarterly, vol. 25, no. 3, pp. 375-406, 1991.

[40] K. S. Goodman, "The Reading Process," in Interactive Approaches to Second Language Reading, P. L. Carrell, J. Devine, and D. E. Eskey, Eds. New York: Cambridge University Press, 1995.

[41] G. Baş, "Reading Attitudes of High School Students: An Analysis from Different Variables," International Journal on New Trends in Education and Their Implications, vol. 3, no. 2, pp. 47-58, 2012.

[42] E. Edge, Teacher Welcome and Teaching Tips in Reading Comprehension Skills and Strategies. Irvine: Saddleback Educational Publication, 2002.

[43] C. Medina, Successful Strategies for Reading in the Content Areas. Huntington Beach: Shell Educational Publishing, 2007.

[44] N. Mohseni Takaloo and M. R. Ahmadi, "The Effect of Learners' Motivation on Their Reading Comprehension Skill: A Literature Review," International Journal of Research in English Education, vol. 2, no. 3, pp. 10-21, 2017, doi: 10.18869/acadpub.ijree.2.3.10.

[45] P. K. Pokharel, "Learning to Read and Reading to Learn in English," Journal of NELTA Surkhet, vol. 5, pp. 75-81, 2018, doi: 10.3126/jns.v5i0.19490.

[46] R. Jemamus, H. Wijaya, and H. Tulak, "The Applying of SOAPS Strategy in Enhancing The Reading Comprehension," presented at the Proceedings of First International Conference on Culture, Education, Linguistics and Literature, CELL 2019, 5-6 August, Purwokerto, Central Java, Indonesia, Makassar, Indonesia, 2019. [Online]. Available: https://eudl.eu/proceedings/CELL/201 9

[47] D.P.Tampubolon, Kemampuan Membaca: Teknik Membaca Efektif dan Efisien. Bandung: Angkasa, 2015.

[48] D. Dalman, Keterampilan Membaca. Jakarta: Rajawali Pers, 2014.

[49] N. Hidayah and F. Hermansyah, "Hubungan antara Motivasi Belajar dan Kemampuan Membaca Pemahaman Siswa Kelas V Madrasah Ibtidaiyah Negeri 2 Bandar Lampung Tahun 2016/2017," Terampil: Journal Pendidikan \& Pembelajaran dasar, vol. 3, no. 2, pp. 1-21, 2016.

[50] P. Dugard and J. Todman, "Analysis of Pre-test-Post-test Control Group Designs in Educational Research," Educational Psychology, vol. 15, no. 2, pp. 181-198, 1995, doi: 10.1080/0144341950150207.

[51] A. Muhid, E. R. Amalia, H. Hilaliyah, N. Budiana, and M. B. N. Wajdi, "The Effect of Metacognitive Strategies Implementation on Students' Reading Comprehension Achievement," International Journal of Instruction, vol. 13, no. 2, pp. 847-862, 2020, doi: 10.29333/iji.2020.13257a.

[52] M. Segura, H. Roquet, and C. Pérez-Vidal, "The Effects of a CLIL Programme on Linguistic Progress at Two Different
Points in Time," Journal of Language and Education, vol. 7 , no. 1, pp. 171-189, 2021, doi: 10.17323/jle.2021.10981.

[53] V.P. Vazquez and M.C.R. Ordonez, "Describing The Use of The L1 in CLIL: An Analysis of L1 Communication Strategies in Classroom Interaction," International Journal of Bilingual Education and Bilingualism, 2018. Doi:10.1080/13670050.2018.1511681

[54] J.A. Merino and D. Lasagabaster, "CLIL As a Way to Multilingualism," International Journal of Bilingual Education and Bilingulism, 2015. Doi: 10.1080/13670050.2015.1128386

[55] H. Brown and A. Bradford, "Differing Approaches and Goals," in Transfornation in Language Education, P. Clements, A. Krause, and H. Brown, Eds. Tokyo: JALT, 2017.

[56] C. M. Marino, "Towards Implementing CLIL (Content and language Integrated Learning) at CBS (Tunja, Colombia)," Colombian Applied Linguistic Journal, vol. 16, no. 2, 2014, doi: 10.14483/udistrital.jou.calj.2014.2.a02.

[57] Y. Kang, H. Hwang, K. Nam, and Y. Choi, "Comparison of Teacher Talk of Korean and Native English-speaking Teachers: On the Efficiency of Delivering Content Knowledge in EFL Contexts," The Journal of Asia TEFL, vol. 7, no. 2, pp. 1-28, 2010.

[58] S. Theporal and J. Sundarsingh, "CLIL Method in Imparting Reading Skills to Secondary level Students-An Experimental Study," Research journal of English Language and Literature, vol. 5, no. 3, pp. 171-174, 2017.

[59] A. Karim and M. M. Rahman, "Revisiting the Content-based Instruction in Language Teaching in Relation with CLIL: Implementation and Outcome," International Journal of Applied Linguistics and English Literature, vol. 5, no. 7, pp. 254-264, 2016, doi: 10.7575/aiac.ijalel.v.5n.7p.254.

[60] D. Coyle, "Listening to Learners: An Investigation into Successful Learning across CLIL Contexts," International Journal of Bilingual Education and Bilingualism, vol. 16, no. 3, pp. 244-266, 2013.

[61] J. Rodriguez-Bonces, "Content and Language Integrated Learning (CLIL): Considerations in The Colombian Context," Gist Education and Learning research Journal, vol. 6, pp. 177-189, 2012.

[62] D. Snow, "English Teaching, Intercultural Competence, and Critical Incident Exercises," Language and Intercultural Communication, 2015, doi: 10.1080/14708477.2014.980746.

[63] J. C. Torres-Rincon and L. M. Cuesta-Medina, "Situated Practice in CLIL: voices from Colombian Teachers," Gist Education and Learning research Journal, vol. 18, pp. 109$141,2019$.

[64] E. Puspitasari, "Classroom Activities in Content and Language Integrated Learning," Journal of Foreign Language Teaching and Learning, vol. 1, no. 2, pp. 1-13, 2016, doi: 10.18196/ftl.129. 